\title{
ArcheoSciences
}

Revue d'archéométrie

$40 \mid 2016$

Varia

\section{The bridge of Dieulouard (Meurthe-et-Moselle, France): a fresh perspective on metal supply strategies in Carolingian economy}

Le pont de Dieulouard (Meurthe-et-Moselle) : un éclairage nouveau sur les stratégies d'acquisition du métal dans l'économie carolingienne

Alexandre Disser, Philippe Dillmann, Marc Leroy, Paul Merluzzo and Stéphanie Leroy

OpenEdition

Journals

Electronic version

URL: https://journals.openedition.org/archeosciences/4830

DOI: 10.4000/archeosciences.4830

ISBN: 978-2-7535-5384-2

ISSN: 2104-3728

Publisher

Presses universitaires de Rennes

Printed version

Date of publication: 30 December 2016

Number of pages: 149-161

ISBN: 978-2-7535-5382-8

ISSN: 1960-1360

Electronic reference

Alexandre Disser, Philippe Dillmann, Marc Leroy, Paul Merluzzo and Stéphanie Leroy, "The bridge of Dieulouard (Meurthe-et-Moselle, France): a fresh perspective on metal supply strategies in Carolingian economy", ArcheoSciences [Online], 40 | 2016, Online since 30 December 2018, connection on 24 February 2022. URL: http://journals.openedition.org/archeosciences/4830 ; DOI: https://doi.org/ 10.4000/archeosciences.4830 


\title{
The Bridge of Dieulouard (Meurthe-et-Moselle, France): A Fresh Perspective on Metal Supply Strate- gies in Carolingian Economy
}

\author{
Le pont de Dieulouard (Meurthe-et-Moselle) : un éclairage nouveau sur les stratégies \\ d'acquisition du métal dans l'économie carolingienne
}

\author{
Alexandre Disser ${ }^{a}$, Philippe Dillmann ${ }^{a}$, Marc Leroy $^{\mathrm{b}}$, Paul Merluzzo ${ }^{\mathrm{b}}$ \\ and Stéphanie Leroy ${ }^{\mathrm{a}}$
}

\begin{abstract}
A rescue excavation has unearthed the remains of a bridge crossing the Moselle River at Dieulouard (Meurthe-et-Moselle, France). This constitutes one of the rare examples of non-religious monumental architecture from the Carolingian period in France. The present archaeometrical study, conducted on a set of architectural iron fastenings, provides an opportunity to examine the modalities through which early medieval building yards acquired ferrous materials. Located within the vicinity of active ironmaking zones, a hypothesis was subsequently put forward that the iron supply was provided by a local market. The results nevertheless highlight a more complex acquisition strategy than expected, relying at least partially on metal salvaging. This study therefore stimulates current discussions of the importance of recycling in the Carolingian economy, and of the value attributed to material and its transformation.

Mots clés : Une opération d'archéologie préventive a révélé les vestiges d'un pont permettant le franchissement de la Moselle à Dieulouard (Meurthe-etMoselle, France). Il s'agit d'un des rares exemples d'architecture monumentale non-religieuse de l'époque carolingienne à l'échelle du territoire français. La présente étude archéométrique, effectuée sur un lot de renforts architecturaux ferreux, offre l'opportunité d'examiner les modalités d'acquisition en matériaux ferreux d'un chantier de construction altomédiéval. Celui-ci sétant déroulé au cour d'une région connaissant une activité sidérurgique non négligeable, l'hypothèse d'une fourniture assurée par un marché local a été privilégiée. Les résultats obtenus mettent toutefois en évidence une stratégie d'acquisition bien plus complexe, reposant au moins partiellement sur la récupération de métal. L'étude de cet ensemble de renforts ferreux permet ainsi d'alimenter les discussions menées actuellement sur l'importance de l'activité de recyclage dans l'économie carolingienne, ainsi que sur la valeur accordée au matériau et à sa transformation.
\end{abstract}

Keywords: Carolingian economy, ironworking activities, provenance studies, recycling, Lorraine.

Mots clés : Economie carolingienne, métallurgie du fer, étude de provenance, recyclage, Lorraine.

\section{INTRODUCTION}

Archaeological and historical research over the last three decades has increased our understanding of iron production and consumption in the early Middle Ages. Excavations of settlements and burials provide substantial documentation about iron consumption modalities related to distinct activities: agriculture, weaponry, craftsmanship, domestic ware... In comparison, the use of metal in early medieval architecture, and particularly during the Carolingian epoch, has

${ }^{a}$ LAPA-IRAMAT, NIMBE, CEA, CNRS, Université Paris-Saclay, CEA Saclay 91191 GIF-SUR-YVETTE, France. (alexandre.disser@cea.fr)(philippe. dillmann@cea.fr) (stephanie.leroy@cea.fr)

b LMC, IRAMAT, UMR5060, CNRS and LAM, Nancy,France. (marc.leroy.lmc@orange.fr) (pmerluzzo@yahoo.fr) 
been characterized far less, despite its fundamental importance. Indeed, sites that may provide necessary material are scarce. Although the use of iron is evidenced during Carolingian times, as in the palatial complex of Aachen (Davis \& McCormick, 2008, p. 284), metallic reinforcements are often inaccessible. Documentary sources, such as account books, that provide important information about medieval building yards, are lacking for the Carolingian period. Consequently, the unearthing in 2005 of two piers of a stone bridge (Gucker \& Legendre, 2006, 2007), built in the late $9^{\text {th }}$ c. ${ }^{1}$ across the Moselle River (Meurthe-et-Moselle, Lorraine, France), provides a rare opportunity to study ferrous clamps implementation modalities in Carolingian monumental architecture. First, it is important to mention that the facings of the stone piers are made of architectural blocks scavenged from monuments in the abandoned Roman town of Scarponna (Boulanger \& Gucker, 2008), located a few hundred meters from the bridge (Figure 1). These stones are fastened by iron clamps. Since reusing architectural materials was common in the Middle Ages, it is likely that iron reinforcements might also have been recovered from the Roman monuments, sparing the effort of forging new clamps. Nevertheless, several production centres from this period in central Lorraine have been the subject of archaeological research conducted over the last three decades on ancient ironmaking activities. The most iconic workshop is located 25 kilometres south of the bridge, under the present village of Ludres (Meurthe-et-Moselle). It operated from the early $8^{\text {th }} \mathrm{c}$. until the late $10^{\text {th }} \mathrm{c}$. Though the extent of activity is unknown, from several dozens to hundreds of tons of metal were produced. Such volumes were probably sufficient to supply numerous regional markets, and even extra-regional commercial networks. Moreover, activities of such magnitude were certainly supervised by some political power that would have controlled and organized both production and distribution activities. The presumed status of this workshop raises crucial questions regarding commercial networks established in this part of Lothringia during Carolingian times. A dozen iron clamps from the Dieulouard bridge piers were studied to provide information about the iron supply strategies implemented by an early medieval building yard. An archaeometric study involving microstructural and chemical characterization of ferrous alloys and slag inclusions was performed on this set, allowing provenance and dating studies.

1. Wooden elements from one of the pier's foundations were dated by dendrochronology from 836 A.D., the date of tree cutting (DendroNEt laboratory, Germany). Two wooden elements fastening stone blocks were dated by radiocarbon (895-1019 A.D. interval; Ly-4132 and 4133).

\section{SAMPLE SET AND EXPERIMENTAL METHODOLOGY}

Forty-three iron reinforcements were collected from the two stone piers. Despite the fact that they were all sealed in lead, preventing them from corroding, their conservation state is variable. Some sustained deformations, and some are fragmented due to the collapsing of the piers. Eleven clamps were selected for the present study. They are formed by a flat part terminated by two pins set at a right angle. Their length ranges from 200 to 250 millimetres, their width from 6 to $8 \mathrm{~mm}$, and their thickness from 33 to $56 \mathrm{~mm}$. The length of the pins is between 33 and $56 \mathrm{~mm}$. The average weight of an entire clamp is 359 grams (minimum: $214 \mathrm{~g}$; maximum: $445 \mathrm{~g}$ ) (Table 1). Pins were crafted in different ways. Clamps 411A1, 489A1 and 1167A1 were formed by folding the metal into an " $\mathrm{S}$ " shape. The other clamps were made by bending the metal extremities back on themselves. The way of making the clamps appears relatively consistent at the scale of the sample set, except for some minor differences observed mainly in the pins.

Some clamps show slight concavities on their edges, suggesting hammering to adjust their width to fit the orifices carved in the stone blocks. Three artefacts (251A1, 510A1, 1219A2) show marks of welding, indicating that two iron pieces were put together to produce fastenings of sufficient length.

Several cuttings were performed for each clamp, either in the longitudinal (251A1, 220A1, 272A1, 411A1, 489A1, 510A1, 1052A1, 1219A2, HSA3) or transverse (100A1, 256A1, 1167A1) axes. The cross-sections were coldmounted in epoxy resin, then prepared for metallographic examination by grinding the surface with $\mathrm{SiC}$ papers (grade 80 to P2400), and finally polishing it using diamond paste ( 3 and $1 \mu \mathrm{m}$ ). All surfaces were examined after Nital etching $\left(3 \% \mathrm{HNO}_{3}\right)$ using an Olympus BX51 optical microscope coupled to a Qimaging CCD camera. Examining microstructures allows reconstruction of the chaine opératoire, and identifies potential thermic (welding, tempering) or thermochemical (cementation) treatments. Furthermore, it enables the definition of the most relevant areas of interest for chemical analyses taking into account microstructural characteristics of both metallic matrix and slag inclusions.

These areas of interest were then examined by Field Emission Gun Scanning Electron Microscopy (FEGSEM), using an accelerating voltage of $15 \mathrm{kV}$. Semi-quantitative analysis of major elements contained in non-metallic inclusions was performed by Energy Dispersive Spectrometry (EDS) using a Silicon Drift Detector (SDD) with a coun- 
Figure 1: Location of main Roman and medieval vestiges around DieulouardScarponna.

Figure 1 : Localisation des principaux vestiges antiques et médiévaux aux alentours de Dieulouard-Scarponne.

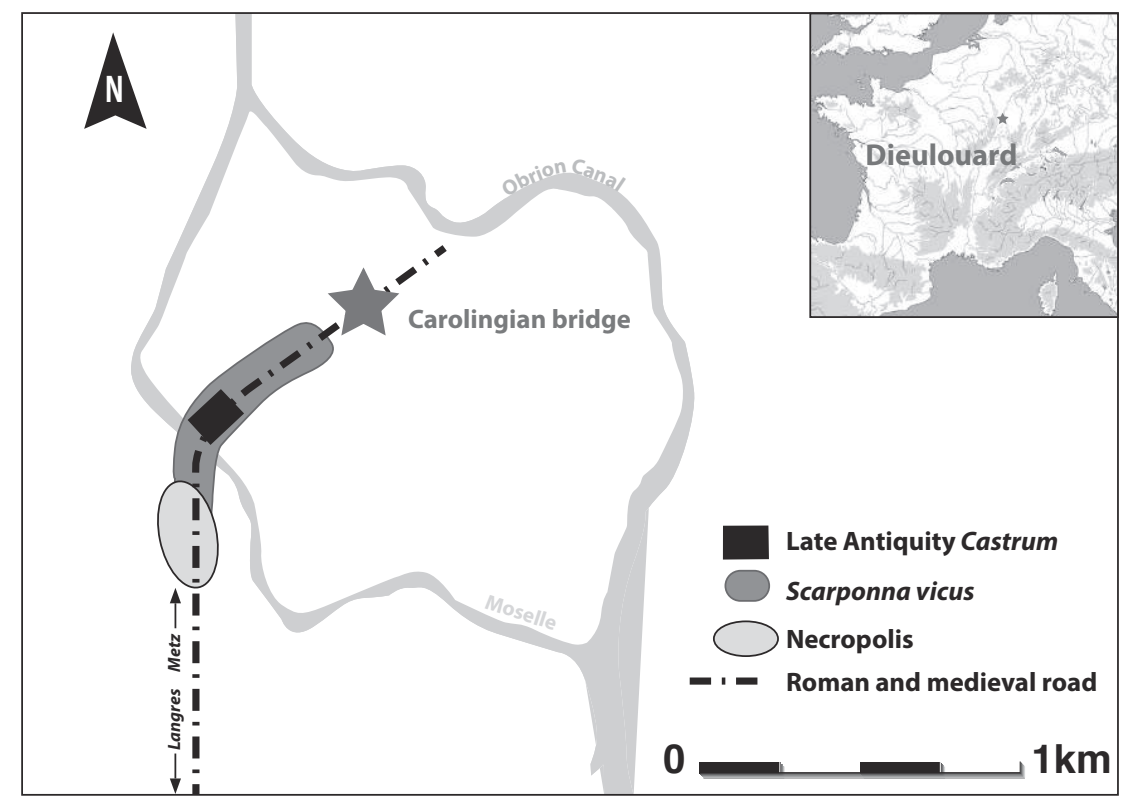

\begin{tabular}{|c|c|c|c|c|c|c|}
\hline Clamp n ${ }^{\circ}$ & Length (mm) & Max. width (mm) & Min. width (mm) & Thickness (mm) & $\begin{array}{l}\text { Average length of } \\
\text { pins }(\mathrm{mm})\end{array}$ & Weight (g) \\
\hline $100 \mathrm{~A} 1$ & 111 cons. & 39 & & 9 & 40 & 145 \\
\hline $251 \mathrm{~A} 1$ & 250 & 40 & 32 & 8 & 43 & 412 \\
\hline 256A1 & 175 cons. & 36 & 31 & 6 & 42 & 201 \\
\hline $272 \mathrm{~A} 1$ & 161 cons. & 32 & 30 & 6 & 37 & 160 \\
\hline 411A1 & 146 cons. & 38 & 30 & 8 & 33 & 235 \\
\hline 489A1 & 225 & 35 & 31 & 8 & 38 & 445 \\
\hline $510 \mathrm{~A} 1$ & 82 cons. & 37 & N/A & 8 & 46 & N/A \\
\hline $1052 \mathrm{~A} 1$ & 224 & 37 & 29 & 8 & 56 & 426 \\
\hline 1167A1 & 270 & 34 & 28 & 8 & 53 & 214 \\
\hline 1219A2 & 196 & 33 & 31 & 8 & 54 & N/A \\
\hline HSA3 & 235 & 36 & 30 & 8 & 43 & 297 \\
\hline Moyenne & 233,33 & 36,09 & 30,22 & 7,73 & 44,09 & 358,80 \\
\hline Écart-type & 25,20 & 2,47 & 1,20 & 0,90 & 7,46 & 186,54 \\
\hline Écart-type relatif & $10,80 \%$ & $6,84 \%$ & $3,98 \%$ & $11,71 \%$ & $16,93 \%$ & $51,99 \%$ \\
\hline
\end{tabular}

Table 1: Measurements made on clamps selected for archaeometrical study Tableau 1 : Dimensions des crampons ayant fait l'objet de l'étude archéométrique

ting rate of about 80,000 counts per second. From several dozens to several hundreds of inclusions were analysed per sample, depending on their cleanliness. The detection limit is estimated at about $0.5 \% \mathrm{wt}$, linked to an accuracy error of $10 \%$. This error is $2 \%$ for elemental amounts above $1 \%$ wt (Dillmann \& L'Héritier, 2007). Samples were analysed by taking into account all major elements potentially contained in non-metallic inclusions. Results are expressed by the following oxides: $\mathrm{Na}_{2} \mathrm{O}, \mathrm{MgO}, \mathrm{Al}_{2} \mathrm{O}_{3}, \mathrm{SiO}_{2}, \mathrm{P}_{2} \mathrm{O}_{5}, \mathrm{SO}_{3}, \mathrm{~K}_{2} \mathrm{O}$, $\mathrm{CaO}, \mathrm{TiO}_{2}, \mathrm{Cr}_{2} \mathrm{O}_{3}, \mathrm{~V}_{2} \mathrm{O}_{5}, \mathrm{MnO}$ and $\mathrm{FeO}$.

The chemical composition of slag inclusions is analysed by a multivariate statistical treatment following the process proposed by Disser et al. (2014), which helps to determine their formation conditions (smelting or forging stages). Among 
inclusions interpreted as formed during the smelting stage, a dozen were submitted to trace element characterization by Laser Ablation-ICP-Mass Spectrometry (LA-ICP-MS) using an Element XR (Thermo Scientific) quadrupole analyser. The frequency of the Nd: YAG laser (wavelength $266 \mathrm{~nm}$ ) is set at $7 \mathrm{~Hz}$. The ablation diameter is set at $80 \mu \mathrm{m}$. The following isotopes were quantified: ${ }^{9} \mathrm{Be},{ }^{28} \mathrm{Si},{ }^{45} \mathrm{Sc},{ }^{47} \mathrm{Ti},{ }^{51} \mathrm{~V}$, ${ }^{52} \mathrm{Cr},{ }^{59} \mathrm{Co},{ }^{60} \mathrm{Ni},{ }^{63} \mathrm{Cu},{ }^{66} \mathrm{Zn},{ }^{69} \mathrm{Ga},{ }^{72} \mathrm{Ge},{ }^{75} \mathrm{As},{ }^{85} \mathrm{Rb},{ }^{88} \mathrm{Sr},{ }^{89} \mathrm{Y}$, ${ }^{90} \mathrm{Zr},{ }^{93} \mathrm{Nb},{ }^{95} \mathrm{Mo},{ }^{108} \mathrm{Pd},{ }^{118} \mathrm{Sn},{ }^{121} \mathrm{Sb},{ }^{133} \mathrm{Cs},{ }^{137} \mathrm{Ba},{ }^{139} \mathrm{La},{ }^{140} \mathrm{Ce}$, ${ }^{141} \mathrm{Pr},{ }^{146} \mathrm{Nd},{ }^{147} \mathrm{Sm},{ }^{153} \mathrm{Eu},{ }^{157} \mathrm{Gd},{ }^{159} \mathrm{~Tb},{ }^{172} \mathrm{Yb},{ }^{178} \mathrm{Hf},{ }^{181} \mathrm{Ta}$, ${ }^{182} \mathrm{~W},{ }^{208} \mathrm{~Pb},{ }^{232} \mathrm{Th},{ }^{238} \mathrm{U}$. Accuracy errors are calculated for each analysis sequence, and are estimated between 5 and $20 \%$ given the nature of the element and its concentration in the inclusion (Gratuze, 1999; Gratuze et al., 2001).

The characteristic chemical signature of inclusions is defined according to an element list selected by S. Leroy et al. (2012) and Disser et al. (in press): $\mathrm{Mg}, \mathrm{Al}, \mathrm{Si}, \mathrm{Ca}, \mathrm{Mn}, \mathrm{Y}, \mathrm{La}$, Ce, Pr, Nd, Sm, Eu, Gd, Th, U. A reference set, composed of 188 ore and smelting slag analyses, was established for the Lorraine region for provenance determination.

This study also used radiocarbon dating of ferrous alloys by accelerator mass spectrometry (AMS). An experimental methodology has been developed recently to efficiently extract the carbon from carbides in steel alloy matrices (S. Leroy et al., 2015). About $1 \mathrm{mg}$ of carbon has to be extracted to proceed with dating, which corresponds to the sampling of about $250 \mathrm{mg} 0.4 \%$ wt $\mathrm{C}$ hypoeutectoid alloy.

\section{Results}

Macroscopic-scale observations indicated that some clamps had been crafted by welding two metal pieces together in order to obtain a sufficient length. Metallographic examinations and microanalyses of non-metallic inclusions were done on eleven selected clamps to determine the microstructural and chemical characteristics of each part.

\section{Metallographic examinations}

The metal structure of the analysed clamps does not vary that much. They all consist of a ferritic matrix, except 510A1. Only a few carburized zones are observed locally. Ghost structures are observed in the ferritic parts of seven artefacts, indicating a heterogeneous distribution of siderophile elements in the metal. These structures are generally linked to phosphorus (Goodway \& Fisher, 1988; Neff \& Dillmann, 2001; Stewart, Charles \& Wallach, 2000; Vega, Dillmann, \& Fluzin, 2002). This particular element, whose presence in metal is due to the smelting of phosphoric ores, has often been employed in previous studies as a criterion for coarsely determining the origin of metallic products, prior to a more precise determination (Buchwald \& Wivel, 1998; Desaulty et al., 2009; S. Leroy et al., 2012; Pagès, Dillmann, Fluzin, \& Long, 2011; S. Paynter, 2006).

All cross-sections show a metallic matrix organized in longitudinal bands distinguished by the size of the ferrite grains, or by the presence or absence of ghost structures (Figure 2). This organization highlights the forging sequences, which mainly consist of deforming the iron following the longitudinal axis to draw the metal bar out. Clamp 510A1 also shows a banded structure, which is described precisely by Tylecote \& Gilmour (1986), Piaskowski (1987) and Blakelock \& McDonnell (2011). In this case, an alternation of more or less carburized bands is visible, from $0.1 \% \mathrm{wt}$ hypoeutectoid alloy to eutectoid steel. The main metallographic features of each sample are summarized in Table 2. Average carbon rates were calculated following the method

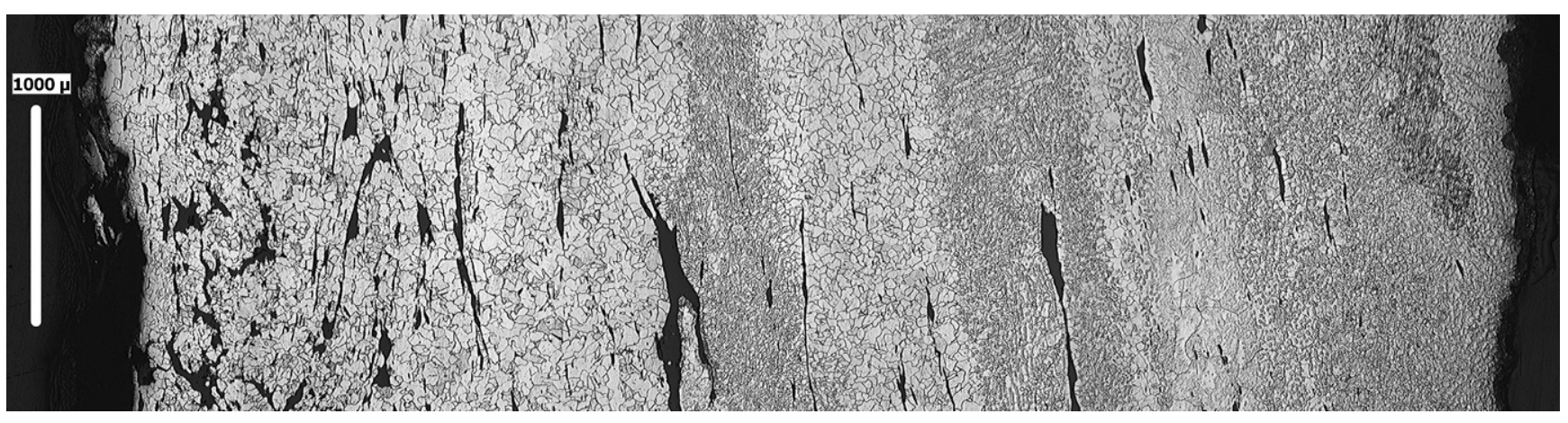

Figure 2: Micrographic photograph showing the alternation of ferritic bands distinguishable by the size of grains, and by the presence of ghost structures.

Figure 2: Cliché micrographique montrant l'alternance de bandes ferritiques qui se distinguent par la taille des grains, ainsi que par la présence de structures fantômes. 


\begin{tabular}{|c|c|c|c|c|c|c|}
\hline Clamp n ${ }^{\circ}$ & Welding lines & Ghost structures & $\begin{array}{c}\text { Relative amount } \\
\text { of ghost struc- } \\
\text { tures }\end{array}$ & $\begin{array}{l}\text { Average carbon } \\
\text { content (\%wt C) }\end{array}$ & $\begin{array}{l}\text { Carburized } \\
\text { surface }(\%)\end{array}$ & $\begin{array}{l}\text { Inclusion proportion } \\
(\%)\end{array}$ \\
\hline $100 \mathrm{~A} 1$ & No & No & & 0.03 & 1.20 & 1.81 \\
\hline 251A1(bar1) & Yes & Yes & ++ & 0.03 & 0.00 & 1.35 \\
\hline 251A1(bar2) & Yes & No & & 0.02 & 0.00 & 0.11 \\
\hline $256 \mathrm{~A} 1$ & No & Yes & + & 0.10 & 17.33 & 0.95 \\
\hline $272 \mathrm{~A} 1$ & No & Yes & +++ & 0.02 & 0.00 & 0.32 \\
\hline 411A1 & No & Yes & + & 0.04 & 0.00 & 0.91 \\
\hline 489A1 & No & Yes & +++ & 0.06 & 12.76 & 3.82 \\
\hline 510A1(bar1) & Yes & No & & 0.36 & 88.77 & 2.35 \\
\hline 510A1(bar2) & Yes & No & & 0.19 & 73.24 & 4.60 \\
\hline $1052 \mathrm{~A} 1$ & No & No & & 0.08 & 11.05 & 2.30 \\
\hline 1167A1 & No & Yes & + & 0.02 & 0.00 & 2.33 \\
\hline 1219A2(bar1) & Yes & Yes & ++ & 0.04 & 0.00 & 1.80 \\
\hline 1219A2(bar2) & Yes & No & & 0.05 & 0.00 & 1.67 \\
\hline HSA3 & No & No & + & 0.02 & 0.00 & 3.32 \\
\hline
\end{tabular}

Table 2: Main metallographic features of the examined clamps.

Tableau 2 : Synthèse des caractéristiques métallographiques des crampons.

defined by Pagès et al. (2008) and L'Héritier et al. (2013). Visible surfaces of each carbon content range $([0.02 \% \mathrm{wt} C$; $0.1 \%],[0.1 \% ; 0.3 \%],[0.3 \% ; 0.5 \%],[0.5 \% ; 0.7 \%],[0.7 \%$; $0.9 \%]$ ) were measured by image analysis. The proportion of carburized zones was determined, given as the ratio between surfaces of alloys superior to $0.3 \% \mathrm{wt} \mathrm{C}$ and the total surface observed.

All clamps show low amounts of inclusions, in all cases lower than $5 \%$ of the observed surface. This cleanliness nevertheless varies considerably with some samples being very clean $(0.1 \%$ for part 2 of clamp 251A 1$)$, while others contain about $4.5 \%$ inclusions $(510 \mathrm{~A} 1)$. It is interesting to notice that clamps 251A1, 510A1 and 1219A2 are each formed by two bars clearly showing distinct metallographic characteristics. Inclusions show three main petrographic features. The first presents a very high proportion of wüstite $(\mathrm{FeO})$, visible as large globules. These inclusions are mainly visible in the vicinity of the welding lines, though they may be found in some cases within the metallic masses (clamp 100A1). The second feature is dominant within the sample set. It consists of a fayalitic matrix, generally finely crystallized, but lathes are also observable. This matrix contains variable amounts of wüstite globules and dendrites. Some spinels (magnetite $\mathrm{Fe}_{3} \mathrm{O}_{4}$, hercynite $\mathrm{FeAl}_{2} \mathrm{O}_{4}$ ) presenting a characteristic angular shape are locally visible in the faya- litic matrix. A totally vitreous slag forms the last feature. Most inclusions have an elongated shape, and are aligned following the longitudinal axis of the cross-sections, which is consistent with the banded organization of metallographic structures. More squatty shaped inclusions with irregular contours are observable locally. Two clamps, 489A1 and $510 \mathrm{~A} 1$, contain many inclusions of this type, concentrated in relatively confined areas. Their density, along with the shape of the inclusions, indicates that the metal of the two clamps is relatively coarse, and did not benefit from intensive forging work.

Microscopic observations, particularly the presence of ghost structures in some cases and the evidence of welding of two metal pieces in others, reveal a relative heterogeneity among the clamp set. These differences indicate that different raw products were used for crafting the artefacts. Furthermore assembling metal pieces to produce these reinforcements may seem surprising given their relatively low weight. They would indeed have been easily obtained from one single bloom. This statement, along with the reuse of stone blocks mentioned above, further supports the practice of metal recycling to produce the clamps. These preliminary conclusions and hypotheses led to the subsequent chemical characterisation of slag inclusions, as well as radiocarbon dating of two ferrous reinforcements. 


\section{Chemical characterization of non-metallic slag inclusions}

Energy dispersive spectrometry analyses are representative of each cross-section observed in terms of the number of slag inclusions analysed, but also regarding their distribution and petrographic features. The aim of this analytical step is to consider all inclusion categories, whether they were formed during the smelting operation or at later stages (refining or smithing). Linking each inclusion to one of these operating steps relies on statistical treatment of their chemical features, using a multivariate method proposed by Disser et al. (2014). The data treatment is performed on the main non-reduced compounds of slag. Its objective is to classify inclusions regarding elemental ratios implying particularly $\mathrm{Mg}, \mathrm{Al}, \mathrm{Si}, \mathrm{K}, \mathrm{Ca}$, and $\mathrm{Mn}$. These ratios are expressed by the logratio transformation procedure developed by Aitchison $(1982,1986)$. Data classification is performed by Hierarchical Cluster Analysis employing Ward's method. In order to evaluate the classification relevance, the inclusion groups created by the analysis are compared through bivariate plots using raw elemental ratios. According to statements made by Charlton et al. (2010) and by Dillmann \& L'Héritier (2007), these plots distinguish inclusions formed by using fluxes or addings during smithing stages from endogenous inclusions formed during the smelting stage. The example displayed in Figure 3 shows results obtained by applying this method to the case of clamp 251A1. By considering both chemical and petrographic information, it may be asserted that the red and green groups are located near a major welding line visible on the median axis of the crosssection, and are therefore generated during post-smelting stages. This is confirmed by a high $\mathrm{Si} / \mathrm{Al}$ ratio, indicating the use of a sandy flux type. Inclusions attributed to the orange group, mainly distributed within the two assembled metal pieces, are probably subject to a phase segregation (Dillmann \& L'Héritier, 2007), which in this case seems to result in an aluminium deficiency. Only inclusions attributed to the blue group are associated with ore smelting, and carry the specific chemical information necessary for identifying the origin of the metal.

This process was applied to all the clamps analysed by SEM-EDS. Some of the inclusions interpreted as formed during ore smelting underwent a trace element chemical characterization by LA-ICP-MS (Centre Ernest Babelon - UMR 5060 IRAMAT, Orléans). In order to describe as well as compare the chemical signatures of the clamps, a Principal Component Analysis was applied. Fifteen logratios, involving the following elements: $\mathrm{Mg}, \mathrm{Al}, \mathrm{Si}, \mathrm{K}, \mathrm{Ca}$, Mn, Y, La, Ce, Pr, Nd, Sm, Eu, Gd, Th, U, were employed
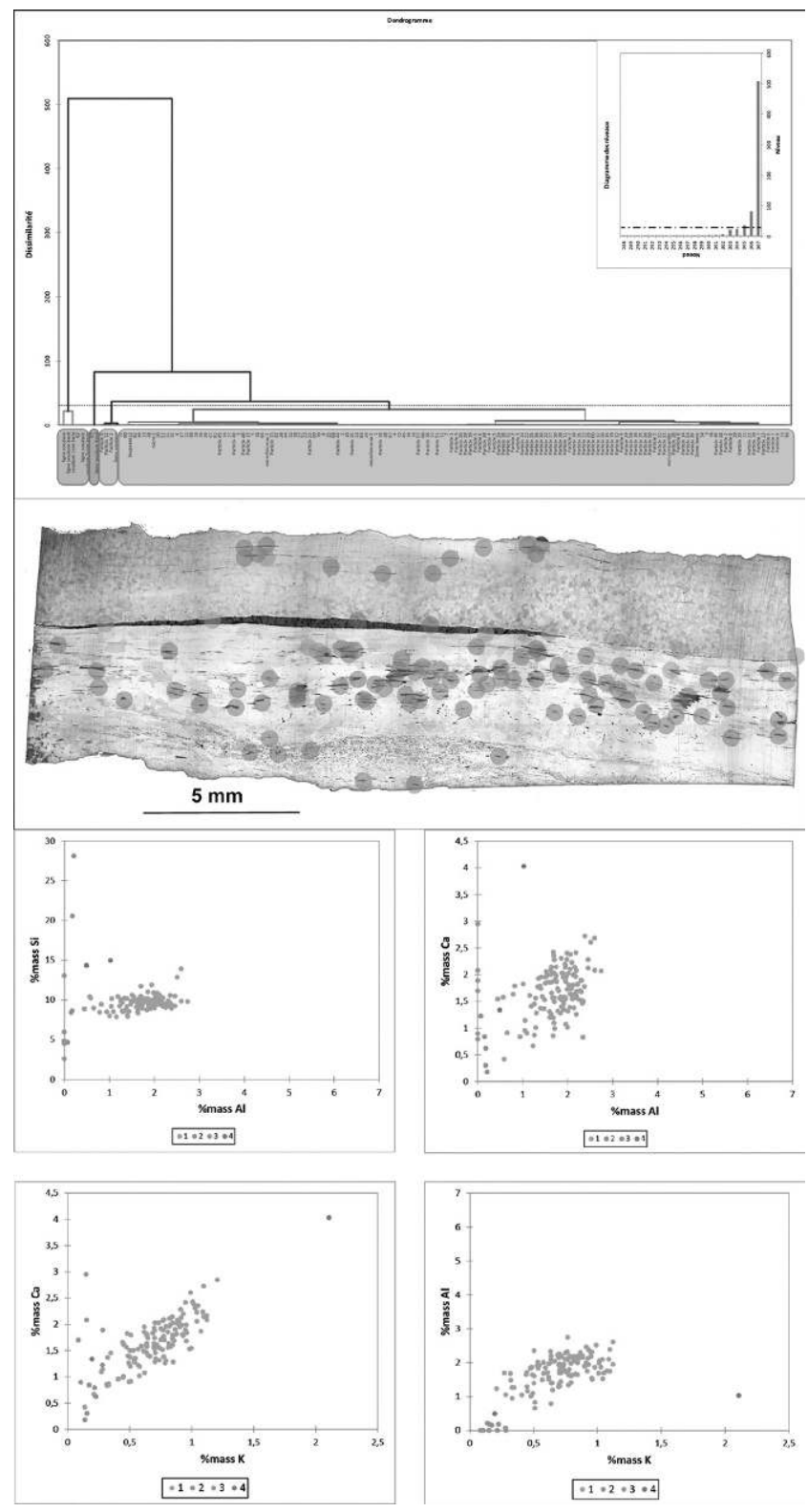

Figure 3: (See colour plate XVII) Interpretation of major element chemical features of the slag inclusions analysed on the 251A1 cross-section. Upper part: dendrogram showing the four classes defined by multivariate analysis; lower part: bivariate description of inclusion classes; middle: distribution of slag inclusion classes on the cross-section.

Figure 3 : (Voir planche couleur XVII) Interprétation de la caractérisation chimique en éléments majeurs des inclusions du crampon 251A1. En haut: dendrogramme montrant les quatre classes d'inclusions définies par l'analyse multivariée ; en bas : description bivariée des classes d'inclusions; au milieu : localisation des classes d'inclusions sur la section polie. 
to describe the 80 inclusions considered. Figure 4 shows the first two factorial planes (and therefore the three factors carrying most of the variance), representing $69.8 \%$ of total variance expressed by the chemical data.

The description of the inclusion chemical signature, relying on both major and trace elements, confirms that the metal used to produce the clamps does not come from a single source. At least two artefacts (215A1 and 510A1) were produced from iron pieces showing chemical signatures clearly distinct from the sample set's main profile. It is also interesting to recall that, in addition to its singular chemical characteristics, clamp 510A1 also shows distinct microstructural features, such as relatively high carbon-content. Furthermore, the slag inclusions have a low iron content (about 10\%wt Fe) compared to the other clamps (from c. 30\%wt to 60\%wt). These features suggest that the metal of 510A1 was formed in distinct smelting conditions, which favoured a better reducing rate for the iron oxides. The two clamps presenting distinct chemical characteristics are also two of the three artefacts showing evidence of welding. Both microstructural and chemical analyses point out the specificity of some clamps within the sample set. This will be further discussed below. Finally, the chemical features of the clamps indicate that the building yard had acquired metal from multiple sources, either provided by metal recycling or by primary distribution networks.

The second alternative will be considered first. The bridge building yard occurred, as mentioned in the introduction, amid an active ironworking environment, as several workshops were producing iron in central Lorraine during Carolingian times. Furthermore, recent research demonstrates that many areas in eastern France were involved in iron production in the late Early Middle Ages (Berranger, 2014; Disser, 2014). These production complexes constitute potential metal providers for the building yard. A chemical database managed by the Laboratoire Métallurgies et Cultures, including especially the PalSid database (Leroy, 1997; Ploquin, 1994; Leroy, Merluzzo, Le Carlier 2015) and the recent results of a $\mathrm{PhD}$ thesis focused on this area, has served as a repository for provenance determination. More precisely, it establishes the specific chemical signature of smelting activities linked to the exploitation of six distinct iron ores within Lorraine. The chemical domains associated with the smelting of each of these ores were compared and distinguished from each other. Those distinct chemical entities, qualified as "production sets", are displayed in Figure 5. Potential chemical compatibilities between the clamps and the production sets will be evaluated to determine whether any of the local production centres could have provided the metal.

A two-step inferential statistical approach (S. Leroy et al., 2014) was applied to question chemical compatibility

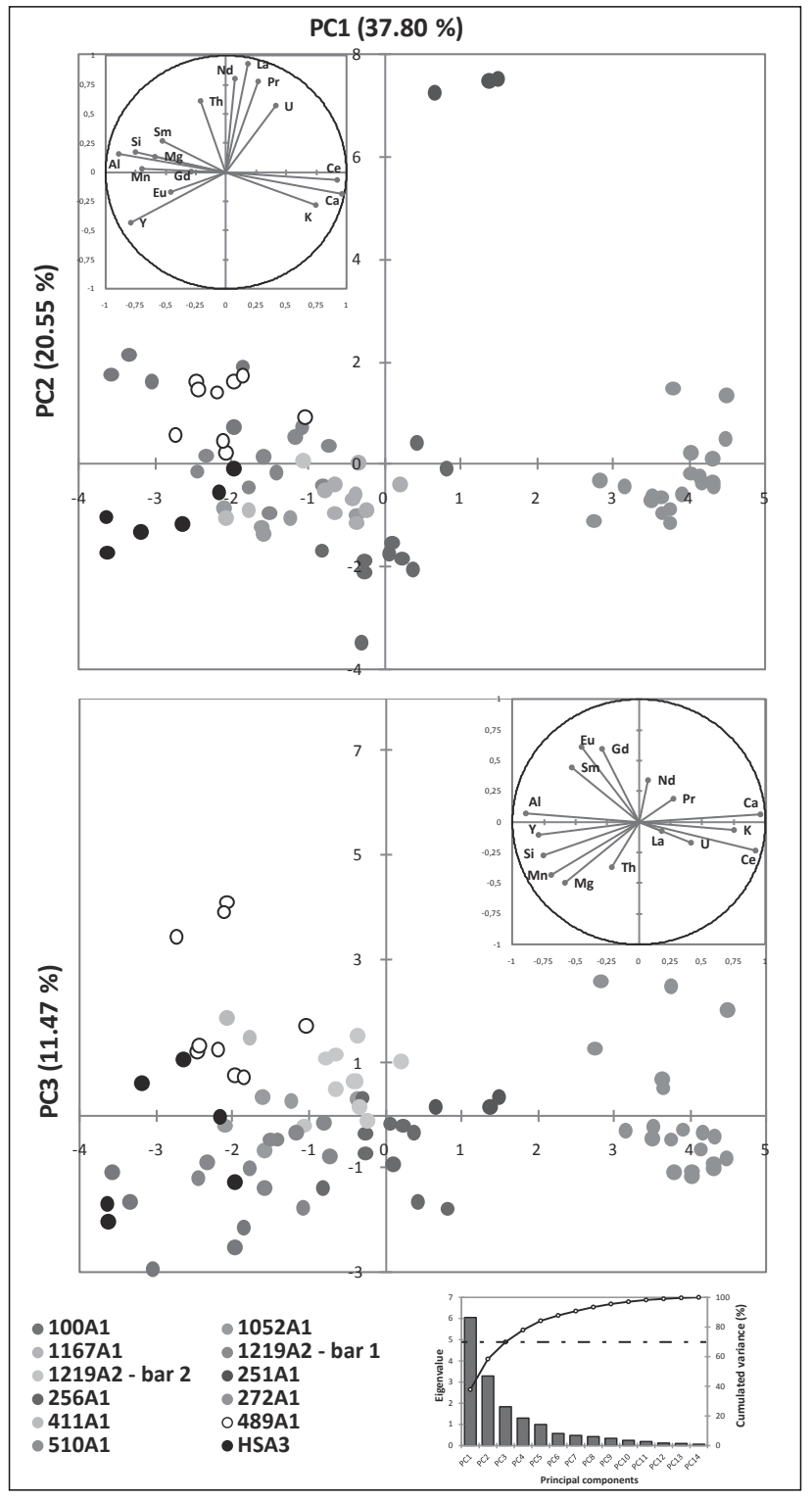

Figure 4: (See colour plate XVIII) (F1-F2) and (F1-F3) factorial planes of PCA performed on the logratios defining the chemical signature of the inclusions analysed for each clamp.

Figure 4 : (Voir planche couleur XVIII) Plans (F1-F2) et (F1-F3) de l'ACP réalisée sur les log-ratios définissant la signature chimique des inclusions analysées pour les crampons.

between the slag inclusions and the production sets from Lorraine. The first stage relies on combining PCA and HCA on both the inclusions and the production sets. It is performed to determine, from among the chemical repository, which production set(s) appear(s) as the most probable metal provider(s). An iron product is de facto considered to be chemically compatible with any of the production sets if 


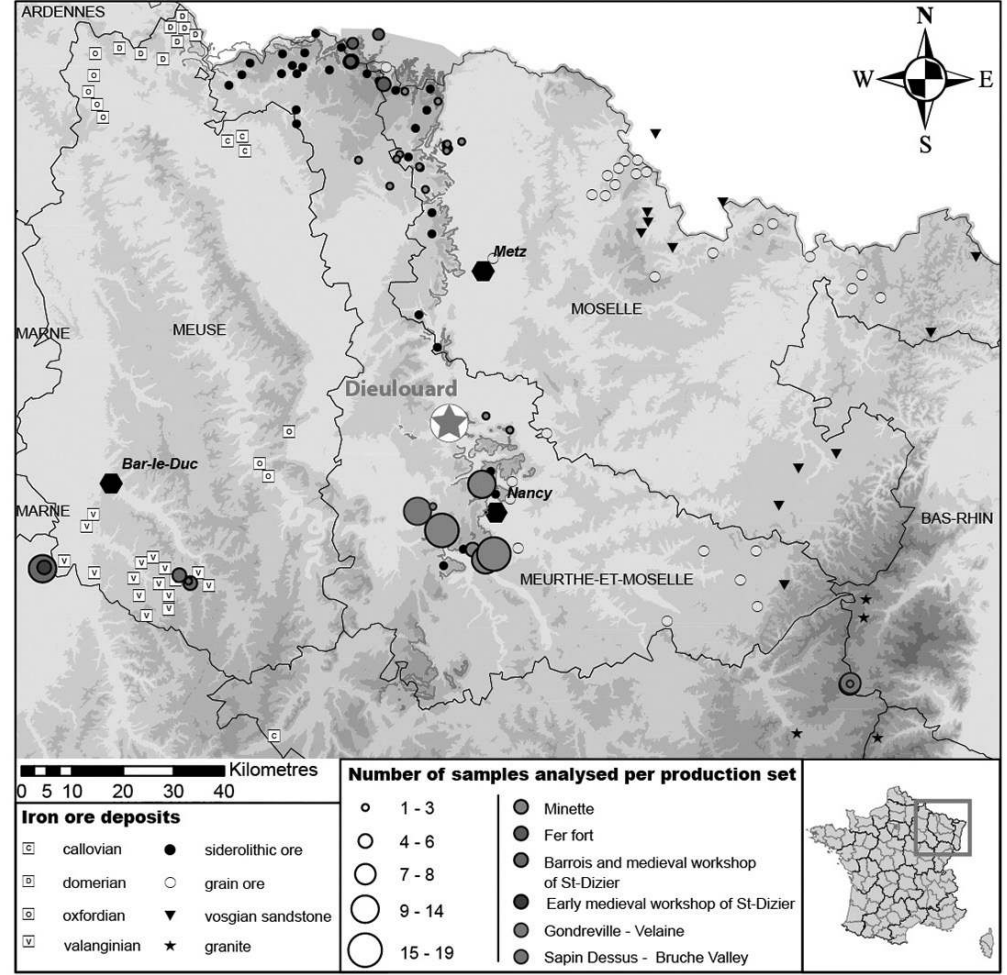

Figure 5: (See colour plate XVIII) Localisation of the main ferriferous deposits surveyed in Lorraine, and of the smelting sites characterised chemically. The colour coding corresponds to the production sets evidenced by (Disser, 2014).

Figure 5: (Voir planche couleur XVIII) Localisation des principaux gites ferriferes connus en Lorraine et des sites de réduction de minerai caractérisés chimiquement. Le code couleur correspond aux ensembles de production mis en évidence dans Disser (2014). they are attributed to the same cluster by the HCA classification. Then a second PCA-HCA combination is applied, but on a limited dataset including exclusively each couple [clamp/potential production set] defined by the first step of the inference. If the inclusions and the potential production set are distinguished by this classification, then the metal was not produced by the corresponding production centres. Otherwise, the production set can be considered with good reliability to be the metal provider. Nevertheless, recall that since some other production sets that are not chemically surveyed may share the same signature, the origin can only be asserted by matching several (chemical, archaeological, historical...) information sources. The first inferential step shows that the metal of nine clamps was not produced by any of the production sets known for early medieval Lorraine (Figure 6). The metal of clamp 251A1 may have been produced by the production set linked to the smelting of a siderolithic ore called "fer fort", whose deposits are mainly located in the northern part of the Moselle Valley. Finally, clamp 510A1 proved to be chemically compatible with the production set related to the smelting of an oolitic ore called "minette", whose vast deposit, stretching over one hundred kilometres, was intensively exploited during medieval times.

These potential origins are nevertheless invalidated by the second classification, since inclusions are clearly distinguished from the potential production sets (Figure 7).
Results obtained at the end of the multivariate process suggest that none of the analysed metal pieces were produced by any of the production sets evidenced for Lorraine in the Early Middle Ages. The hypothesis of a local metal supply appears to be disproven. These results will be discussed more thoroughly below.

\section{Dating of two clamps}

Considering macro- and microscopic observations, the possibility of recycling used metal to produce the clamps was also considered. Proof of the dismantling of Roman monuments has been provided by the reuse of lapidary elements coming from the vicus of Scarponna and surrounding necropolises, suggesting that the metal used by the bridge building yard could also have been a product of architectural spolia. Only two clamps (510A1 and 256A1) contained iron carbides in sufficient amounts to perform radiocarbon dating. Two measures were performed for each clamp. The results are shown in Figure 8.

The measures obtained from the two samples from clamp $256 \mathrm{~A} 1$ are coherent and indicate that the metal is contemporary with the bridge building, at the end of the $8^{\text {th }}$ or $9^{\text {th }}$ century. It can thus be assumed that in this case the metal was in circulation as the building took place. Measures on clamp 510A1, formed from two assembled metal pieces, are on the contrary clearly different, and both precede the 


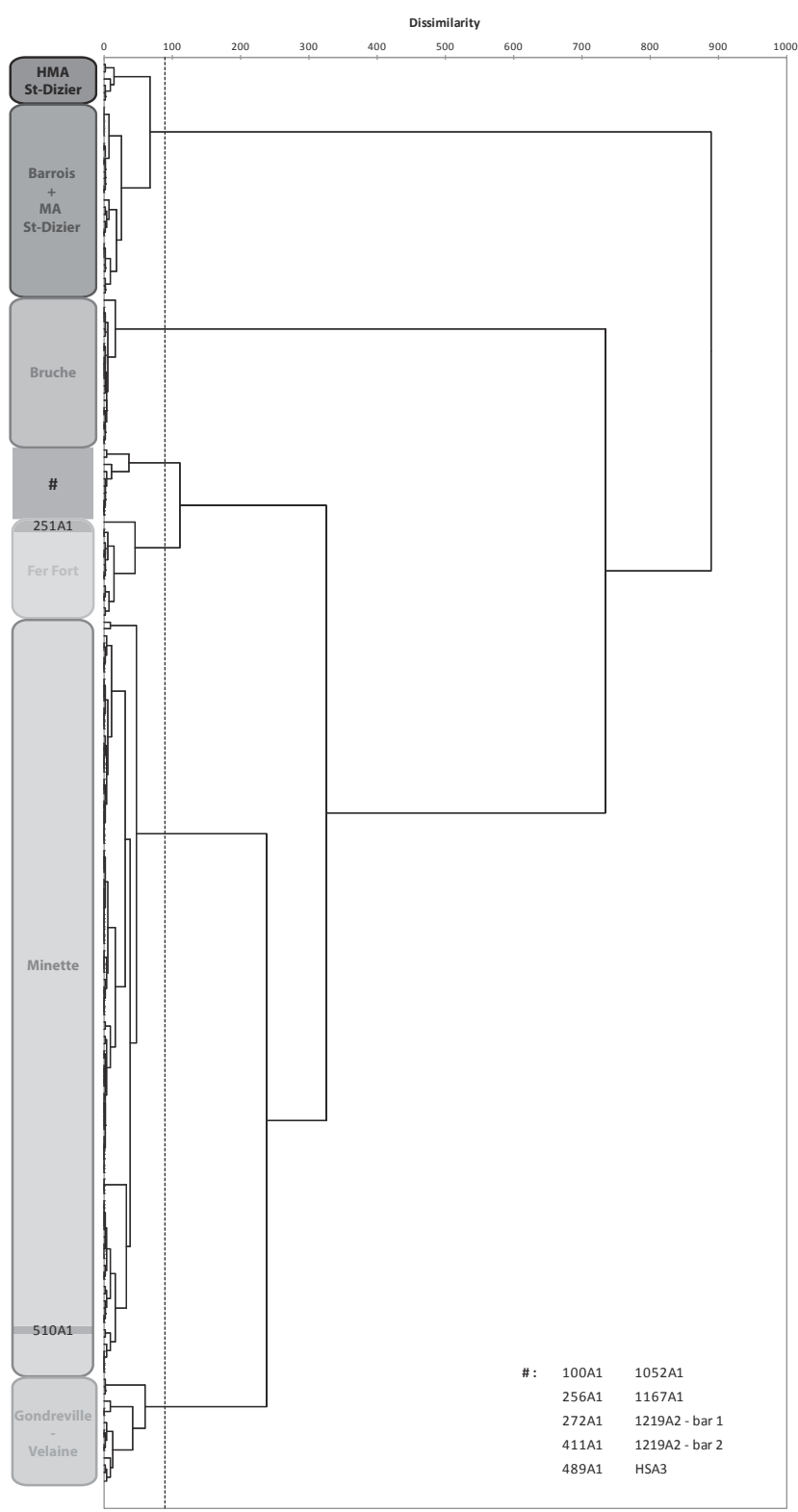

Figure 6: (See colour plate XIX) Dendrogram showing the result of the hierarchical clustering performed on the chemical signature of each clamp and on the chemical domains of the production sets identified in Lorraine

Figure 6: (Voir planche couleur XIX) Dendrogrammes présentant les résultats des classifications ascendantes hiérarchiques réalisées sur la signature chimique des onze crampons, ainsi que sur les domaines chimiques des ensembles de production identifiés au sein de l'espace lorrain

building. The first would have been produced during Late Antiquity or the Early Middle Ages $\left(5^{\text {th }}-6^{\text {th }}\right.$ c.), while the second is dated from Merovingian times $\left(7^{\text {th }}-8^{\text {th }}\right.$ c.). These results indicate that this clamp was indeed formed by assembling "old iron" obtained by recycling.

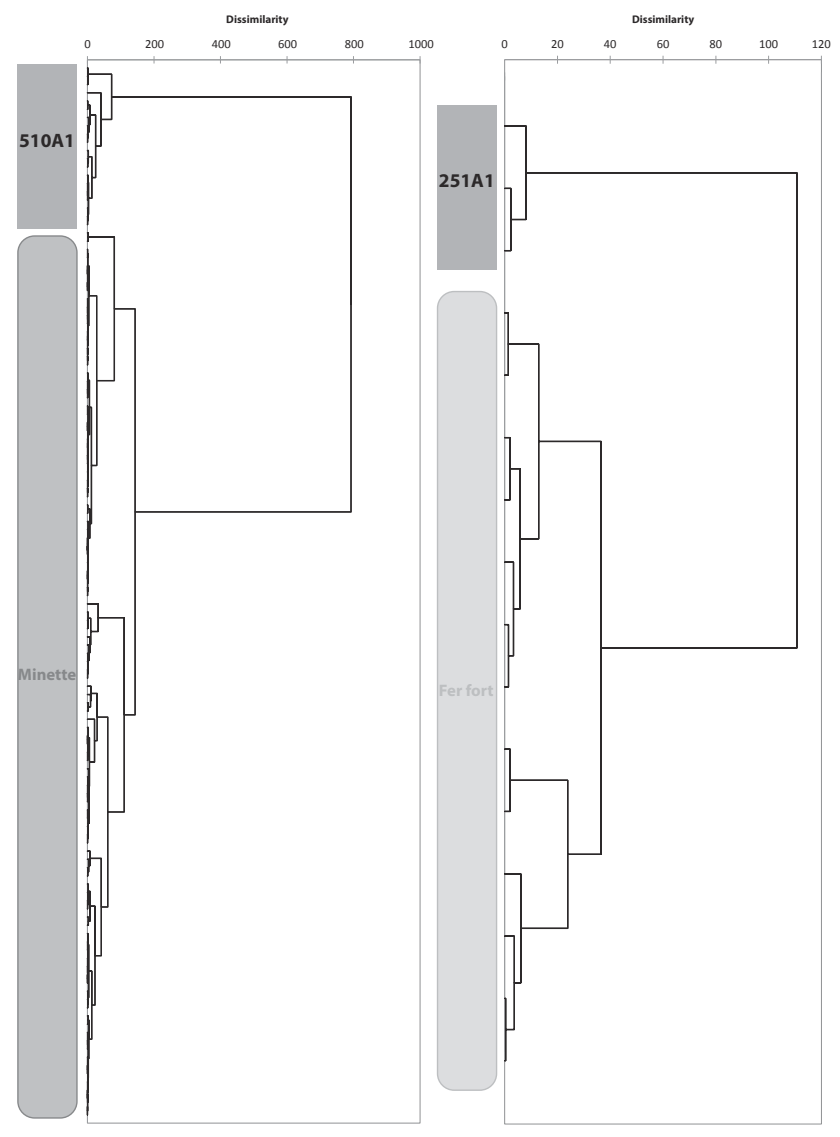

Figure 7: (See colour plate XX) Dendrogram showing the results of the hierarchical clustering performed to assert the provenance hypotheses regarding clamps 510A1 and 251A1.

Figure 7 : (Voir planche couleur XX) Dendrogrammes présentant les résultats des classifications ascendantes hiérarchiques réalisées sur les inclusions des crampons 251A1 et 510A1, ainsi que sur le domaine chimique des ensembles de production candidats.

\section{DisCuSSION}

The study performed on some ferrous reinforcements unearthed by the excavation of an early medieval bridge at Dieulouard provided a rare opportunity to explore the metal supply strategies of monumental building yards during Carolingian times. The fact that sizeable smelting activities took place at this time in central Lorraine led to the hypothesis that local and regional exchange networks provided the supply of metallic materials.

This privileged hypothesis was rejected by the archaeometrical study. It is unlikely that the metal used to make the clamps was produced by workshops exploiting local ores, not even the aalenian oolitic ore deposits ("Minette") that are located only few kilometres from the bridge. In general, the chemical features of the clamps do not correspond to 


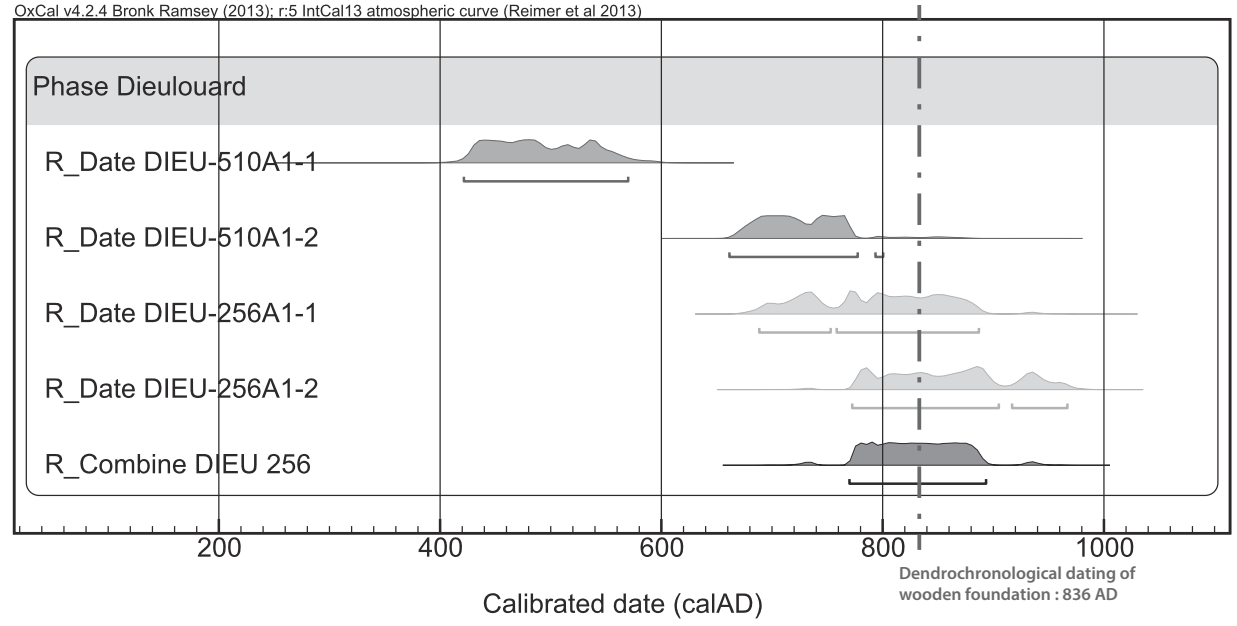

Figure 8: (See colour plate XX) Radiocarbon dating, after calibration (using IntCal 13), of clamps 510A1 and 256A1.

Figure 8: (Voir planche couleur XX) Datation radiocarbone, en âge calibré (d'après IntCal 13), des crampons 510A1 et 256A1. any currently known iron production set for the Lorraine area. While it cannot be completely ruled out, the possibility of a metal supply provided by an undiscovered local ironmaking complex is small, due to the significant number of surveys and excavations conducted in this sector ${ }^{2}$. Furthermore several distinct chemical signatures have been identified among the sample set analysed. This statement leads to the assumption of a multiplicity of iron sources, as well as more complex acquisition modalities than expected.

What were the potential metal sources? A first possibility would be that metal was obtained through a large-scale market relying on multiple iron production centres characterized by distinct chemical signatures. Nevertheless, the results obtained through this study favour the recourse to material salvaging. Whatever the chronological context, recycling appears to be a means of material acquisition whose importance should not be underestimated. For instance, written sources highlight the importance of this phenomenon during the Late Middle Ages (Dillmann \& L'Héritier, 2009; L'Héritier et al., in press). Bernard (2009) discussed the salvaging of materials at the end of the Roman Empire and through succeeding periods. This investigation demonstrates that the salvaging of architectural metal was a full-fledged activity practiced in a rational way. The retrieval was sometimes performed opportunistically on ruined buildings, but in other cases it was carried out in a planned manner on still-functional buildings, carefully stripped of their metallic elements. The example of Letôon in

2. The erection of the castle of Dieulouard (Deus loux warde, i.e. Godward) by Haimont, bishop of Verdun, is asserted at the beginning of $11^{\text {th }}$ c. It once controlled some part of the Moselle Valley surrounding the antic Scarponna (Parisse, 1990). It is highly possible that the territory controlled by this castle had been under the influence of Verdun diocese at least since the $9^{\text {th }}-10^{\text {th }} \mathrm{c}$. The iron used at Dieulouard might have come other diocesan territories, e.g. in the northern part of the actual Meuse department, about 100 kilometres afar.
Lycia accurately illustrates this activity (Bernard 2009). The location of an early Christian church, the temple was initially stripped of its sole colonnade. Some evidence gathered from lapidary elements (entablatures and column drums) suggests that metal salvaging was the main motivation. Meanwhile probe holes were dug into still-standing walls, at the exact location of fastening elements. Similar observations have been made in the city of Rome on the Pantheon, as well as on the temple of Antoninus and Faustina. Of course profane buildings were not spared either, as evidenced by the facade of the Colosseum, which is literally riddled with holes. The latter building can be considered as an actual "mine", since more than 300 tons of metal would have been implemented in its masonry.

The bridge at Dieulouard accurately illustrates this phenomenon in Lorraine during the Early Middle Ages, at least regarding the lapidary elements provided by the dismantling of the monumental complex of the Roman vicus of Scarponna, as well as the surrounding necropolises (Boulanger \& Gucker, 2008). Given this context, it is conceivable that some of the metallic elements used by the building yard may have been obtained in the same way. Although the radiocarbon dating available for the ferrous reinforcements from Dieulouard does not currently validate an origin from Late Antiquity, it indicates a reliance on metal salvaging for supplying the building yard. But was the metal obtained by stripping architectural elements, or by recycling "old iron" such as worn-out tools? The first possibility is preferable in our opinion, given the very distinct "life expectancy" of ferrous objects according to their function. Architectural iron can conserve its integrity for centuries, while the expected lifetime of agricultural tools does not exceed a few years, according to ethnographical studies led on African communities (Serneels, 2007). Moreover some of the clamps, including 256A1, appear to be contemporary 
with the bridge construction, and could have been provided by trading networks. This possibility is questionable, since the chronological resolution of radiocarbon dating is not sufficient to assert whether the metal would be directly provided by primary trade, or by salvaging "old iron" still in use. Taking into account all the observations made on this set of ferrous reinforcements, recycling nevertheless appears dominant.

Evidence of this activity at Dieulouard contributes to defining the value attributed to iron during the Early Middle Ages, reflected by its acquisition modalities. It has to be stressed that early medieval iron has been traditionally considered a rare material whose crafting would have been the preserve of few craftsmen due to a relative technological regress (for example Chapelot \& Fossier [1980, p. 24-25] or Duby [1973, p. 22-25]). This conception, relying on the assumed perception of a relative material and intellectual pauperization, has been questioned by more recent research (Arnoux, 1993, p. 16-17). The value accorded to ironmaking activities and metallic equipment by the Carolingian documentation cannot be invoked to assert iron rarity in material culture, especially for agricultural and artisanal spheres. This is moreover supported by recent archaeological findings, especially excavations of metallurgical workshops (M. Leroy, 2008; M. Leroy et al., 2015). They reveal the diversity of ironworking organization forms, as well as the importance of production volumes. This conveys the impression that iron was relatively easily acquired, that its production was carried out with expertise at least equal to that of Roman craftsmen, and that the means of production met the demands of the iron market during Carolingian times. What advantage would be gained, at least in domestic, agricultural and artisanal spheres, from acquiring longrange-traded iron whose use did not require a priori specific qualities? Furthermore, relatively easy access to this material would not prevent methodical metal salvaging from buildings, which were perhaps first and foremost dismantled for acquiring building stone. Beyond saving by not buying fresh metal, significant savings in ironmaking and smithing efforts would also be made. Dismantling of ancient buildings and salvaging of metallic elements would not be, in this case, the doings of craftsmen driven to extremes by the rarity of metal. Rather it would have been a full-fledged activity, contributing to the early medieval economy, and maybe adapted in this case to a specific use, masonry reinforcement in monumental architecture. Recall that salvaging Roman ferrous clamps would have enabled almost immediate reuse by the bridge building yard, without much smithing work. The value of the work would prevail, in this case, over the intrinsic value of the material.

\section{Acknowledgements}

Much gratitude is owed to Bernard Gratuze (Centre Ernest Babelon-IRAMAT) for hosting the LA-ICP-MS analyses, and to Emmanuelle Delqué-Kolic and Bernard Bertier (Laboratoire de Mesure du Carbone 14, CEA Saclay) for the dating of two clamps.

\section{Bibliography}

Aitchison J., 1982. The Statistical Analysis of Compositional Data. Journal of the Royal Statistical Society. Series B (Methodological), 44: 139-177.

Aitchison J., 1986. The statistical analysis of compositional data. London, Chapman\&Hall.

Arnoux M., 1993. Mineurs, férons et maîtres de forge. Etude sur la production du fer dans la Normandie du Moyen Âge, XI'$X V^{e}$ siècles. Paris, CTHS.

Bernardi P., 2009. Le bâti ancien comme source de profits. Une facette du rapport entre architecture et économie. In J.-F. Bernard, P. Bernardi, D. Esposito, P. Dillmann, L. Foulquier, R. Mancini (ed.), Il Reimpiego in Architettura. Recupero, Trasformazione, Uso, Roma, École française de Rome/de Boccard, 503-516.

Bernard J.-F., 2009. À propos de l'architecture antique comme source d'approvisionnement en métaux. In J.-F. Bernard, P. Bernardi, D. Esposito, P. Dillmann, L. Foulquier, R. Mancini (ed.), Il Reimpiego in Architettura. Recupero, Trasformazione, Uso. Roma, École française de Rome/de Boccard, 41-50.

Berranger M., 2014. La métallurgie du fer en Bourgogne et en Franche-Comté. Organisation et circulation des productions (VIII s. av. J.-C.-Ve s. apr. J.-C.) (Rapport de PCR No. $n^{\circ}$ 2014/16) (p. 208), Besançon, SRA de Franche-Comté.

Blakelock E., McDonnell G., 2011. Early medieval knife manufacture in Britain; a comparison between rural and urban settlements (AD 400-1000). In J. Hosek H., Cleere L. Mihok, The archaeometallurgy of iron. Recent Developments in Archaeological and Scientific Research. Institute of Archaeology of the ASCR, Praha, 123-136.

Boulanger K., Gucker D., 2008. Le réemploi de blocs antiques dans le pont carolingien de Dieulouard-Scarponne (Meurthe-et- Moselle). Antiquités Nationales, 39: 173-180.

Buchwald V.F., Wivel H., 1998. Slag analysis as a method for the characterization and provenancing of ancient iron objects. Materials Characterization, 40: 73-96.

Chapelot J., Fossier R., 1980. Le village et la maison au Moyen Age. Paris, Hachette.

Charlton M.F., Crew P., Rehren T., Shennan S.J., 2010. Explaining the evolution of ironmaking recipes - An example 
from northwest Wales. Journal of Anthropological Archaeology, $29: 352-367$.

Davis J.R., McCormick M., 2008. The Long Morning of Medieval Europe: New Directions In Early Medieval Studies, London, Ashgate.

Desaulty A.-M., Dillmann P., L'Heritier M., Mariet C., Gratuze B., Joron J.-L., Fluzin P., 2009. Does it come from the Pays de Bray? Examination of an origin hypothesis for the ferrous reinforcements used in French medieval churches using major and trace element analyses. Journal of Archaeological Science, 36: 2445-2462. [http://doi.org/DOI 10.1016/j.jas.2009.07.002].

Dillmann P., L'Héritier M., 2007. Slag inclusion analyses for studying ferrous alloys employed in French medieval buildings: supply of materials and diffusion of smelting processes. Journal of Archaeological Science, 34: 1810-1823.

Dillmann P., L'Héritier M., 2009. Récupération et remploi du fer pour la construction des monuments de la période gothique. In J.-F. Bernard, P. Bernardi, D. Esposito, P. Dillmann, L. Foulquier, R. Mancini (ed.), Il Reimpiego in Architettura. Recupero, Trasformazione, Uso, Roma, École Française de Rome, 157-176.

Disser A., 2014. Production et circulation du fer en Lorraine (VI s. av. J.-C. $-X v^{e}$ s. apr. J.-C.). Belfort, Université de Technologie de Belfort-Montbéliard.

Disser A., Dillmann P., Bourgain C., L'Héritier M., Vega E., Bauvais S., Leroy M., 2014. Iron reinforcements in Beauvais and Metz Cathedrals: from bloomery or finery? The use of logistic regression for differentiating smelting processes. Journal of Archaeological Science, 42 : 315-333. [http://doi. org/10.1016/j.jas.2013.10.034].

Disser A., Dillmann P., Leroy M., L'Héritier M., Bauvais S., FLuZIN P., in press. Iron supply for the building of Metz cathedral: new methodological development for provenance studies and historical considerations. Archaeometry.

Duby G., 1973. Guerriers et Paysans. VII'-XII siècles. Premier essor de l'économie européenne. Gallimard, Paris.

Goodway M., Fisher R. M., 1988. Phosphorus in low carbon iron: Its beneficial properties. Historical Metallurgy, 22 : 21-23.

Gratuze B., 1999. Obsidian characterisation by laser ablation ICP-MS and its application to prehistoric trade in the Mediterranean and the Near East: sources and distribution of obsidian within the Aegean and Anatolia. Journal of Archaeological Science, 26: 869-881.

Gratuze B., Blet-Lemarquand M., Barrandon J.-N., 2001. Mass spectrometry with laser sampling: A new tool to characterize archaeological materials. Journal of Radionalytical and Nuclear Chemistry, 247: 645-656.
Gucker D., Legendre J.-P., 2006. Dieulouard (Meurthe-etMoselle). "Sur le vieux pont”. Archéologie Médiévale, 36: 252253.

Gucker D., Legendre J.-P., 2007. Dieulouard (Meurthe-etMoselle). "Sur le vieux pont”. Archéologie Médiévale, 37: 185186.

LEROY M., 1997. La sidérurgie ancienne en Lorraine avant le hautfourneau. Etude du développement historique et des conditions techniques de l'utilisation du minerai oolithique lorrain (la minette) en métallurgie de réduction directe (Vol. 18). Paris, Éditions du CNRS.

Leroy M., 2008. Les modes de production du fer au haut Moyen Âge. L'exemple des ateliers sidérurgiques de Lorraine centrale. In J. Guillaume, E. Peytremann (ed.), L’Austrasie. Sociétés, économies, territoires, christianisation. Actes des XXVI ${ }^{\text {es }}$ journées internationales d'archéologie mérovingienne, Nancy, 22-25 sept. 2005. Paris, CID, 177-188.

Leroy M., Merluzzo P., Le Carlier C., 2015. Archéologie du fer en Lorraine. Minette et production du fer en bas fourneaux dans l'Antiquité et au Moyen-Âge.

Leroy S., Cohen S. X., Verna C., Gratuze B., Téreygeol F., Fluzin P., Dillmann P., 2012. The medieval iron market in Ariège (France). Multidisciplinary analytical approach and multivariate analyses. Journal of Archaeological Science, 39: 1080-1093.

Leroy S., Dillmann P., Disser A., L'Héritier M., Bauvais S., FLuZIN P., 2014. Provenance et circulation des alliages ferreux. In P. Dillmann, L. Bellot-Gurlet (ed.), Circulation des matériaux et des objets dans les sociétés anciennes. Paris, Éditions des Archives Contemporaines, 79-108.

Leroy S., L'Héritier M., Delqué-Kolic E., Dumoulin J.-P., Moreau C., Dillmann P., 2015. Consolidation or initial design? Radiocarbon dating of ancient iron alloys sheds light on the reinforcements of French Gothic Cathedrals. Journal of Archaeological Science, 53: 190-201. [http://dx.doi. org/10.1016/j.jas.2014.10.016.

L'Héritier M., Dillmann P., Aumard S., Fluzin P., 2013. Iron? Which iron? Methodologies for metallographic and slag inclusion studies applied to ferrous reinforcements from Auxerre Cathedral. In J. Humphris T. Rehren (ed.), World of Iron. London, Archetype Books , 409-420.

L'Héritier M., Disser A., Leroy S., Dillmann P., in press. Récupérer et recycler les métaux les matériaux ferreux au Moyen Âge : des textes à la matière. In L'objet au Moyen Âge et à l'époque moderne : fabriquer, échanger, consommer et recycler. Actes du XI ${ }^{\mathrm{e}}$ congrès international de la Société d'Archéologie Médiévale, Moderne et Contemporaine. Caen, Presses universitaires de Caen. 
Neff D., Dillmann P., 2001. Phosphorus localisation and quantification in archaeological iron artefacts by micro-PIXE analyses. Nuclear Instruments and Methods, 181: 675-680.

Pagès G., Dillmann P., Fluzin P., Long L., 2011. A study of the roman iron bars of Saintes-Maries-de-la-Mer (Bouchesdu-Rhône, France). A proposal for a comprehensive metallographic approach. Journal of Archaeological Science, 38: 1234-1252.

Pagès G., Long L., Fluzin P., Dillmann P., 2008. Réseaux de production et standards de commercialisation du fer antique en méditerranée : les demi-produits des épaves romaines des Saintes-Maries-de-la-Mer (Bouches-du-Rhône, France). Revue Archéologique de Narbonnaise: 261-283.

PAYNTER S., 2006. Regional variations in bloomery smelting slag of the iron age and romano-british periods. Archaeometry, 48: 271-292.

Piaskowski J., 1987. A standardisation procedure for the presentation of the results of metallographic examinations of early iron implements. In B.G. Scott, H. Cleere, R.F. Tylecote (ed.), The crafts of the blacksmith. Belfast, Ulster Museum, 169-178.
Ploquin A., 1994. PalSid. Un prototype de base de données paléosidérurgiques. In M. Mangin (ed.), La sidérurgie ancienne de l'Est de la France dans son contexte européen. Actes du colloque de Besançon, 10-13 novembre 1993. Paris, Les Belles Lettres, 83-84.

Serneels V., 2007. L'économie du fer protohistorique : de la production à la consommation du métal. In P.-Y. Milcent (ed.), L'économie du fer protohistorique : de la production à la consommation du métal. Actes du XXVIII ${ }^{\mathrm{e}}$ colloque international de l'AFEAF, Toulouse, 20-23 mai 2004. Bordeaux, Fédération Aquitania, 425-434.

Stewart J.W., Charles J.A., Wallach E.R., 2000. Ironphosphorus-carbon system. Part I to III. Materials Science and Technology, 16: 275-303.

Tylecote R.F., Gilmour B.J.J., 1986. The metallography of early ferrous edge tools and edged weapons. BAR, Oxford.

Vega E., Dillmann P., Fluzin P., 2002. Contribution à l'étude du fer phosphoreux en sidérurgie ancienne. La Revue d'Archéométrie, 26: 197-208. 


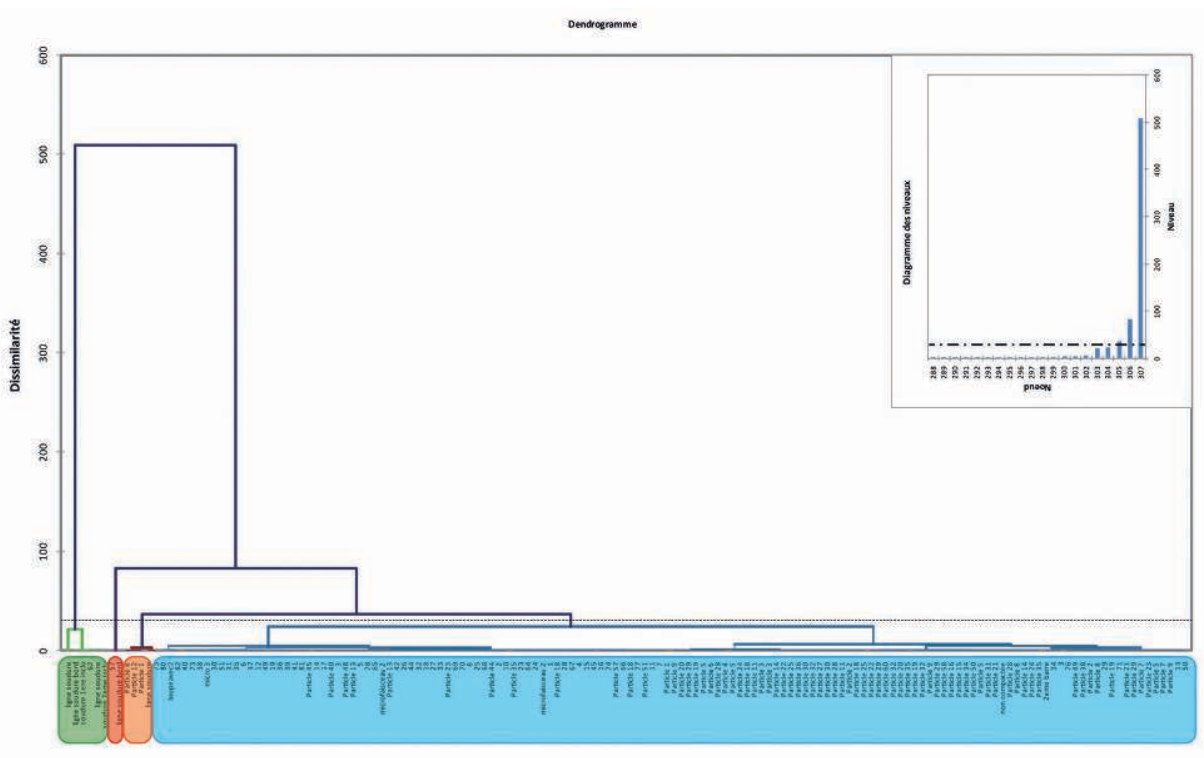

Figure 3 : Alexandre Disser et al., The Bridge of Dieulouard (Meurtheet-Moselle, France): A Fresh Perspective on Metal Supply Strategies in Carolingian Economy (p. 154)

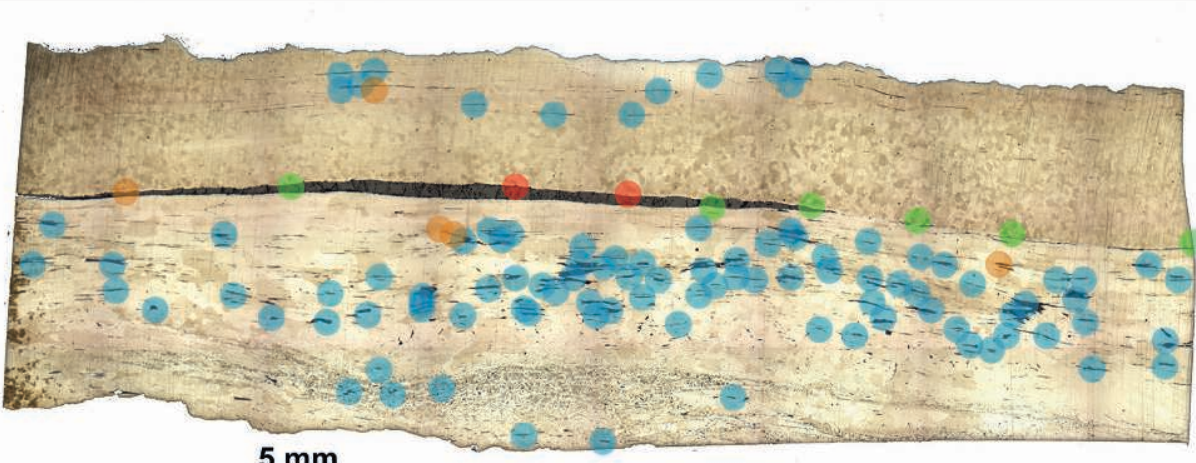

$5 \mathrm{~mm}$

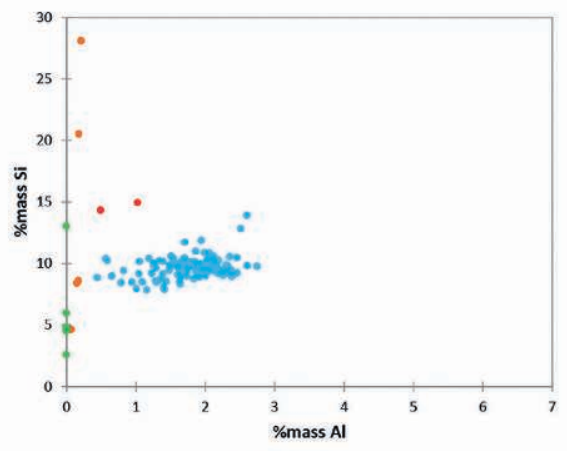

$0102.3 \circ 4$
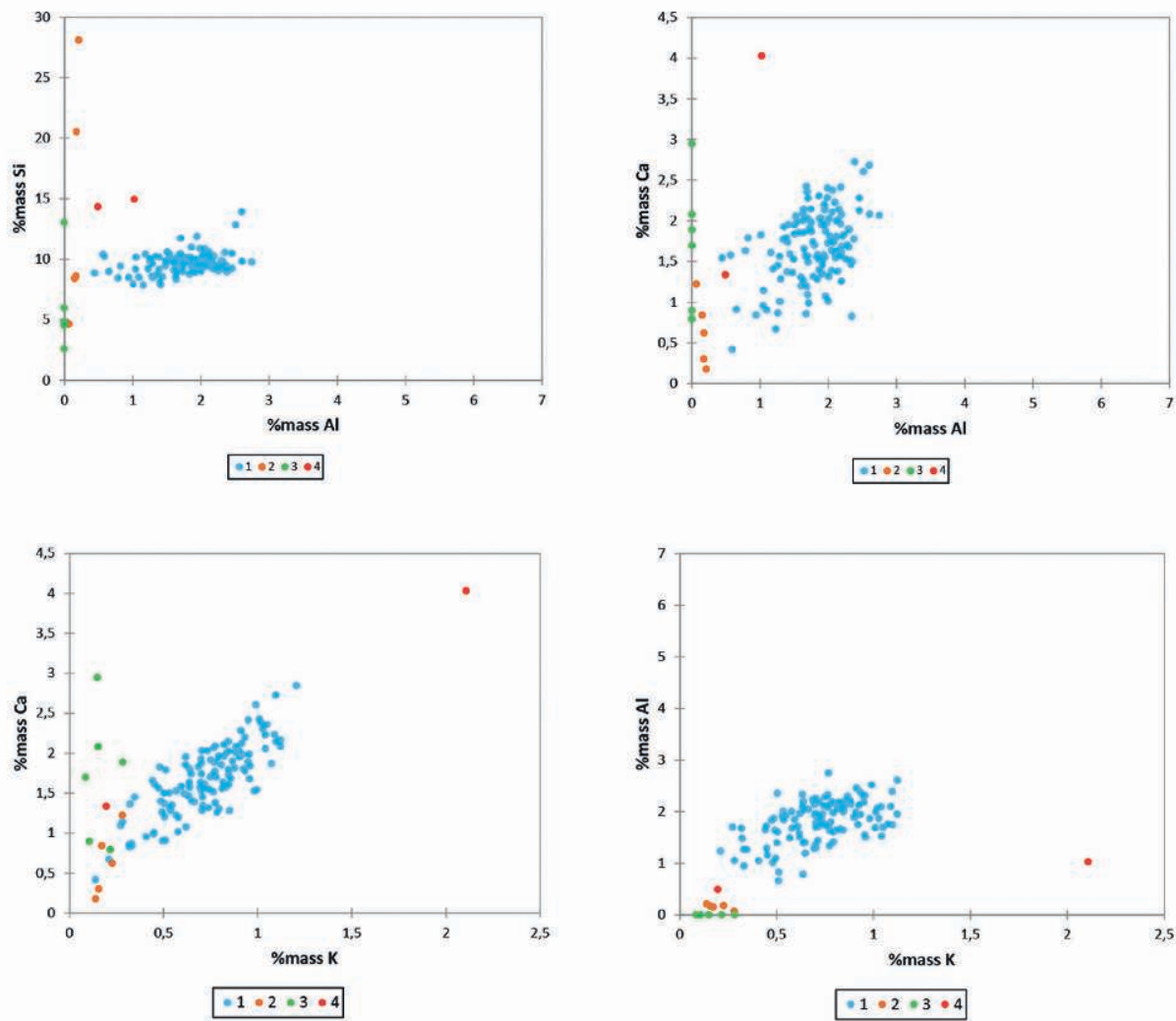

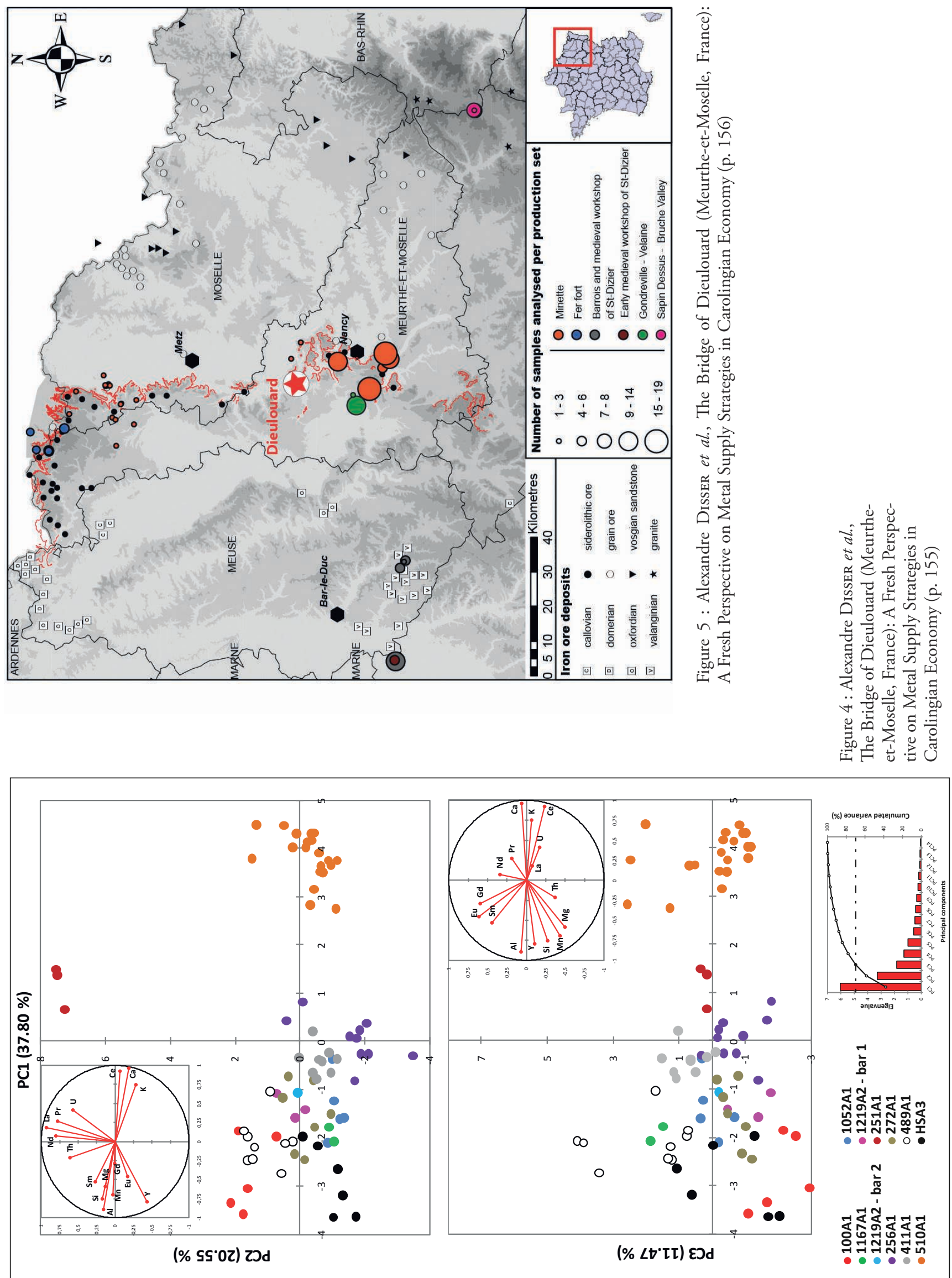


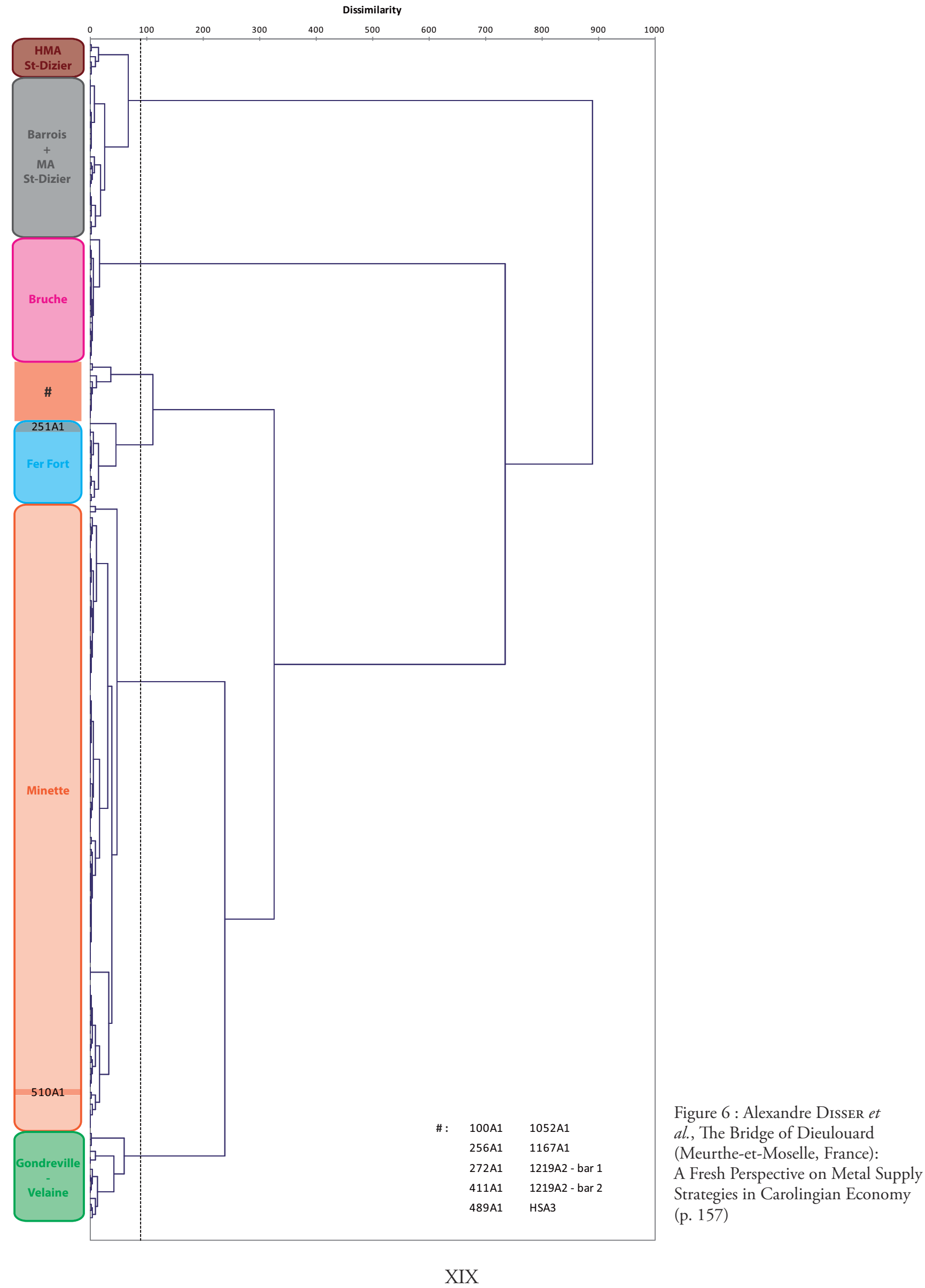



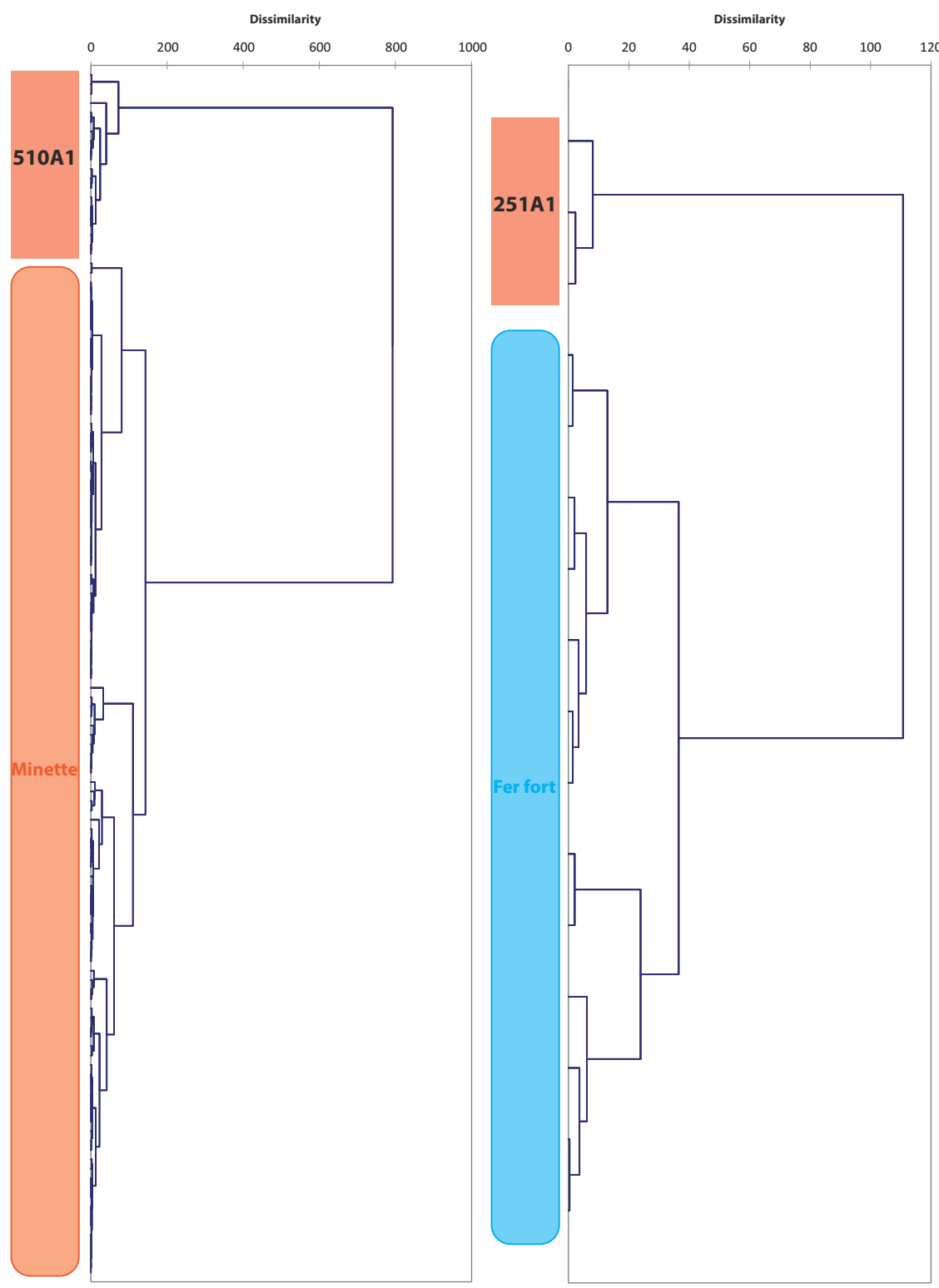

Figure 7 : Alexandre Disser et al., The Bridge of Dieulouard (Meurthe-et-Moselle, France): A Fresh Perspective on Metal Supply Strategies in Carolingian Economy (p. 157)

Figure 8 : Alexandre Disser et al., The Bridge of Dieulouard (Meurthe-et-Moselle, France): A Fresh Perspective on Metal Supply Strategies in Carolingian Economy (p. 158)

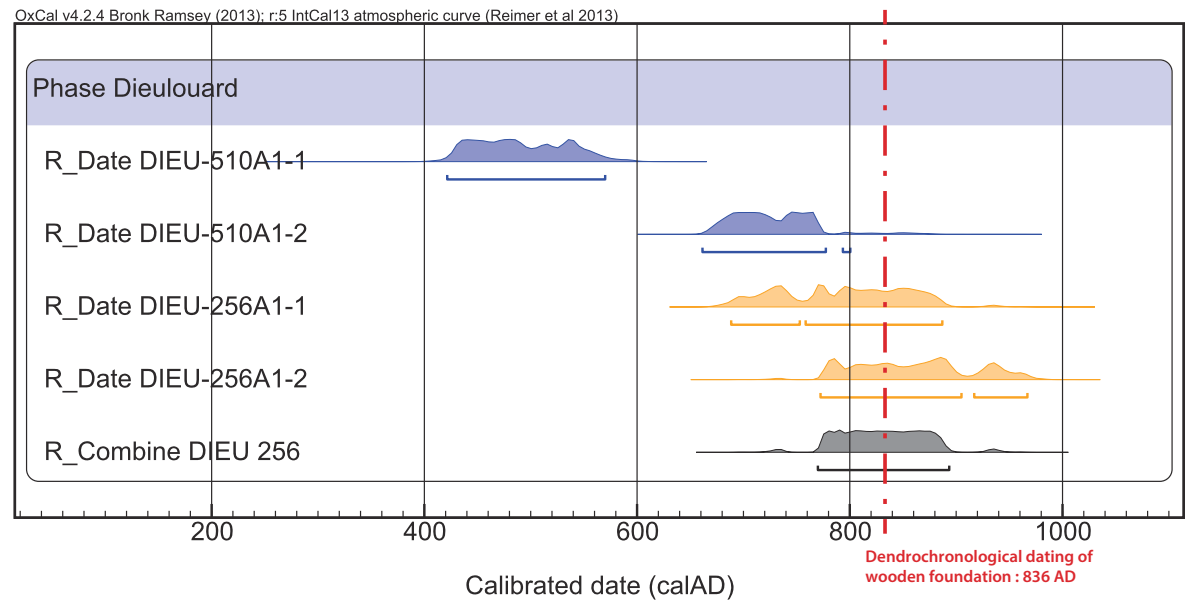

